\title{
Dynamic Popular Channel Surfing Scheme for Reducing the Channel Seek Distance in DTV
}

\author{
Seung-Gwan Lee*, Jin-Hyuk Choi * \\ DTV에서 채널 탐색 거리를 줄이기 위한 선호 채널 동적 배치 방법 \\ 이 승 관 ${ }^{*}, \quad$ 최 진 혁*
}

\begin{abstract}
Due to the increasing availability and popularity of digital television (DTV), the numbers of TV channels and programs that can be selected by consumers are also increasing rapidly. Therefore, searching for interesting channels and program via remote controls or channel guide maps can be frustrating and slow. In this paper, in order to better satisfy consumers, we propose a dynamic channel surfing scheme that reduces the channel seek distance in DTV. The proposed scheme dynamically rearranges the channel sequences according to the channel currently being watched to reduce the channel seek distance. The results of a simulation experiment demonstrate that the proposed dynamic channel surfing scheme reduces the channel seek distance for DTV channel navigation when up-down channel selection interfaces are used.
\end{abstract}

- Keyword : Channel Recommendation, Dynamic Channel Surfing, Channel Seek Distance, DTV

\section{요 약}

디지털 방송이 본격화되고 디지털 텔레비젼의 보급이 일반화되면서 시청자가 선택할 수 있는 채널의 수와 프로 그램의 수는 기존 텔레비젼 환경과 비교하여 시청자가 이용할 수 있는 프로그램 리소스들이 큰 폭으로 증가되고 있 다. 이러한 변화로 수백 개의 채널에서 시청자가 자신이 선호하는 프로그램 채널을 찾기 위해서 리모컨이나 방송 편 성표를 통해 검색하는 것은 많은 시간과 노력이 필요하다. 따라서, 본 논문에서는 up-down 채널 리모컨를 이용해 선호하는 프로그램 채널을 선택하는 시청자들을 위해, 현재 시청하는 채널을 기준으로 선호 프로그램 채널을 동적 으로 배치함으로써 채널의 탐색 거리를 줄이는 방법을 제안한다. 그리고, 실험을 통해 그 성능을 평가한다.

- Keyword : 채널 추천, 동적 채널 배치, 채널 탐색 거리, 디지털 텔레비전

- 제 1 저자, 교신저자 : 이승관

• 투고일 : 2010. 11. 05, 심사일 : 2010. 12. 01, 게재확정일 : 2010. 12.16.

* 경희대학교 국제캠퍼스 학부대학 교수( The College of Liberal Arts, Kyung Hee University ) 


\section{INTRODUCTION}

Due to the increasing availability and popularity of digital television (DTV), the numbers of TV channels and programs that can be selected by consumers are also increasing rapidly.

Historically, a limited number of content providers, including licensed TV radio broadcasting companies and a small number of cable and satellite broadcasting operators, provided only a limited number of channels and programs. Consumers could easily navigate to preferred channels or programs using remote controls and channel/program guides.

However, with the inception of digital broadcasting, channel searching has become more difficult due to the hundreds of available channels and programsand requires a long channel seek time. For such 'multi channel and multi source' domains, a new generation of channel recommendation system is needed in order to reduce the channel seek distance when up-down channel selection interfaces are used.

Generally, consumers use DTV channel selectors to select popular channels via two types of interfaces, including up-down buttons and agent-based channel recommendation systems [1]. Up-down buttons are used to sequentially search the channels, while agent-based channel recommendation systems are used to select the desired contents using a consumer's profile and stored information regarding channel and program preferences [2]. Based on this customized information, personalized Electronic Program Guides (pEPGs) are generated and provided to consumers.

Fig. 1 depicts the selection of popular channels for two types of interfaces using up-down buttons, either by selecting popular channels in lists of recently watched channels (A), or by using a popular channel list (B).

Conventional approaches regarding channel recommendations are classified as either content-based channel recommendation approaches [3]-[5], cooperative channel recommendation approaches [2], [6]-[8], hybrid filtering approaches that provide content-based filters by cooperative channel filtering [9], [10], client-server based channel recommendation approaches for next generation EPG systems [11], [12], and IP-based personalized mosaic EPG service[19]. Some studies have also been conducted to reduce the zapping time required to search for popular channels [1], [16]-[18].

Using popular channel selection interfaces that incorporate up-down buttons as general channel selectors, greater channel seek times or channel seek distances are required as the number of channels and programs increases. To refine these channel selection processes, we propose a dynamic channel surfing scheme designed to reduce channel seek distance in DTV.

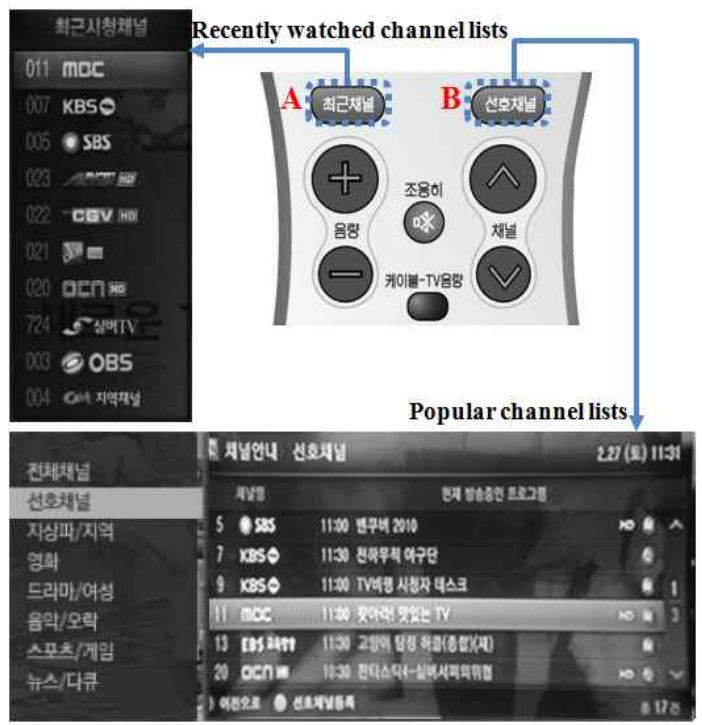

Fig. 1. Channel selection based on popularity 그림 1. 선호 채널 선택

(A: Recently watched channel lists, B: Popular channe lists)

In associated research, Lee et al. introduced a frequency interleaved ordering scheme to reduce channel seek distance [1]. The scheme first fixes the position of the most popular channel in the center, and then arranges channels with odd rankings on the left side, and channels with even rankings on 
the right side by frequency priority. However, since the scheme arranges the fixed channels depending on the position of the most popular channel, consumers who watch the low priority channel change the channel to the high priority channel, spending a great deal of channel seek time and distance.

The scheme proposed in this paper dynamically rearranges channels according to priority around the position of the channel currently being watched, which allows consumers to find popular channels without spending a large amount of channel seek distance in most cases.

We survey conventional approaches and their problems in Chapter II, and propose a new system in Chapter III. We evaluate and analyze the performance of the proposed system in Chapter IV, and conclude this paper in Chapter V.

\section{Background}

Personalization makes it quick and easy to dynamically find channels based on a consumer's channel preferences and enables easy access to those channels. A recommendation system is necessary to implement such personalization.

Agent-based DTV channel recommendation systems are generally divided into the following methods.

Content-based recommendation systems compare a recommendation list to a user's previous input data or compare preference items and recommend the most common items [3]-[5]. Kurapati et al. introduced a multi-agent TV recommender and an electronic program guide that implements both an explicit and an implicit profile using content-based filtering [5].

Collaborative recommendation systems generally adopt the nearest neighbor method proposed in GroupLens [13]. The nearest neighbor method recommends items according to the preferences of the target consumer. However, if preference information is scarce, the accuracy of recommendation is unacceptably low. Typical collaborative recommendation systems are described in [2], [6]-[8]. Lee et al. introduced a recommendation method with a preference program that uses collaborative filtering for each multi-agent, which is a client-server architecture [6]. Sotelo et al. introduced content recommendation for homogeneous and heterogeneous groups of people based on TV-Anytime descriptions of the TV contents [2].

Methods that combine recommendations from multiple profiles use combined multiple filtering, such as user preference ratings. This combined recommendation method maintains the advantages of other methods while reducing the drawbacks. Combined recommendation uses content-based filtering and an analysis of the consumer's rating results to predict new user ratings for areas that may be of interest. There are many multiple content filtering recommendation methods based on collaborative filtering [9], [10]. Pessemier et al. introduced a method of preference advertising tailored to individual users based on get patterns in multiple devices such as iDTV, internet, and mobile devices [9]. Martinez et al. introduced a channel recommendation method using singular value decomposition (SVD) technology and context matching, in order to solve the user scarcity problem in collaborative filtering [10].

A variety of research has been conducted to reduce zapping time in popular channel searches. Lee et al. introduced the most recently selected (MRS) and most frequently selected (MFS) schemes to efficiently recommend channels [14]. Bahn et al. introduced the combined recency and frequency-based selection (CRFS) scheme of combining the MRS and MFS [15]. Lee et al. introduced a frequency interleaved ordering scheme to reduce the channel seek distance more efficiently than the MFS scheme [1]. Cho et al. introduced the adjacent groups join-leave method to reduce the 
channel zapping delay in IPTV [16]. Mamun-Or-Rashid et al. introduced a framework to acquire a user's channel surfing behavior and then proposed an algorithm to mine the user's preferred channel sequences to reduce the channel zapping delay [17] Kim et al. introduced a method of pre-joining the expected next TV channels in order to reduce the IPTV channel zapping time by considering the channel surfing behavior and the particular preferences of each viewer [18].

\section{Dynamic Channel Surfing Scheme}

In this paper, we propose a dynamic channel surfing scheme to reduce the channel seek distance in DTV.

Fig. 2 shows various conventional channel arrangement schemes using up-down buttons for general channel selection [1]. Figs. 2(a), 2(b), and 2(c) show channel sequences of the numerical ordering, frequency circular ordering, and frequency interleaved ordering schemes, respectively. In Fig. 2, there are 24 total channels, and the ring represents the circular structure of the channel sequences. The number in each cell represents the frequency priority, and the numbers outside the cell are the channel numbers. In Fig. 2(a), which represents the conventional channel selection interface using up-down buttons, consumers spend more channel seek time or channel seek distance as the number of channels and programs increases. To refine this method and reduce channel seek distance, Fig. 2(b) represents a frequency circular ordering scheme using the MFS scheme [14], and Fig. 2(c) represents the frequency interleaved ordering scheme [1].

However, because the frequency circular ordering scheme and the frequency interleaved ordering scheme use fixed channel arrangements with the most popular channel in the center, when consumers seek a low priority channel instead of a high priority channel, the channel seek distance is large.
In this paper, we propose a scheme that uses a dynamic channel rearrangement scheme that assigns priority around the position of the channel currently being watched regardless of the current channel's actual priority, as shown in Fig. 3. In this scheme, consumers can search for popular channels without spending a large amount of channel seek time.

Fig. 3 represents the channel selection method based on the frequency priority of the channel selection order established in Fig. 2. This scheme uses the Up-button to move the left channels, and the Down-button to move the right channels. In Fig. 3 , the channel currently being watched (Ch. 3) is designated as the highest frequency priority (1) channel. From there, if the second highest priority (2) channel (Ch. 15) is chosen, the channel seek distance should only be 1 . To achieve this, the position of the second highest priority (2) channel (ch.15) must be in the center, and the other channels are arranged to the left or right side according to their frequency priorities.

In general, consumers tend to select high priority channels. The proposed method places popular channels near the channel currently being watched, so that consumers can find their favorite channels without a large channel seek distance. When the priority of a channel is significantly different than the changed channels, only a small channel seek distance is needed.

There is one problem with the dynamic channel rearrangement as described thus far. In the cases shown in Figs. 3(f) and 3(i), it is necessary to press the Up-button two times to move from the priority (1) channel to the priority (4) channel. When a button is pressed each time, if all of the channels are dynamically rearranged by priority, the movement to a low-frequency priority channel is almost impossible. In other words, when the Up-button is pressed once, the channel is changed to the priority (2) channel. Then, if channels are dynamically rearranged, it becomes impossible to move to the low-frequency priority channel. 
To solve this problem, we determine whether the consumer is in watching mode or surfing mode at the selected channel based on the staying time. In order to determine the mode, a threshold time is set. The standard decision mode is as follows. If the time spent at a channel is longer than the threshold time, the user is assumed to be in watching mode. Otherwise, if the time spent at a channel is shorter than the threshold time, then the user is assumed to be in surfing mode.

In watching mode, the consumer is determined to be watching a particular channel. In this case, we rearrange the other channels on the left or right side dynamically according to the frequency priority around the position of the channel currently being watched.

In surfing mode, the consumer is determined to be surfing toward the next step to search for a popular channel. In this case, we ignore the currently selected channel and then proceed to the next channel, and the dynamic channel rearrangement does not occur.

Fig. 4 shows an example of the proposed dynamic channel surfing scheme compared with the numerical ordering, frequency circular ordering, and frequency interleaved ordering schemes [1]. In the conventional numerical ordering scheme, the total seek distance is 86. In the frequency circular list scheme, in which the channels are sorted by their frequency priority, the total seek distance is 18 , which is $20.9 \%$ of the numerical ordering distance. In the frequency interleaved ordering scheme, the total seek distance in this scheme is 14 , which is $16.3 \%$ of the numerical ordering distance. The total seek distance of the dynamic channel surfing scheme is 12 , which is only $14 \%$ of the numerical ordering, and which performs even better than other methods.

Fig. 4 demonstrate the performance of the proposed dynamic channel surfing scheme, illustrating that the proposed method is a more efficient system

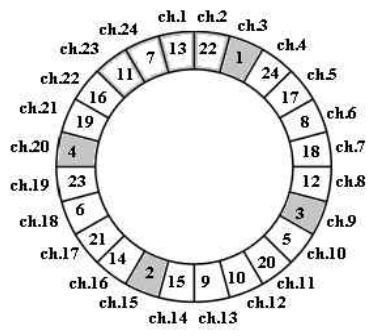

(a) Numerical ordering

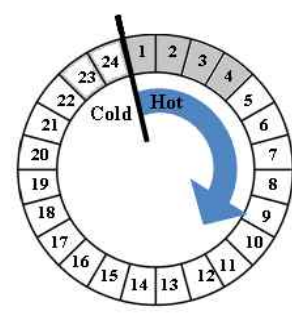

(b) Frequency circular ordering

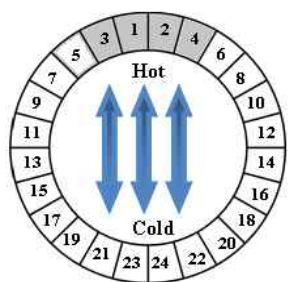

(c) Frequency interleaved ordering

Fig. 2 Channel sequences for numerical ordering and popular channel concentration schemes [1].

그림 2 일반적인 채널 배치 방법[1] 


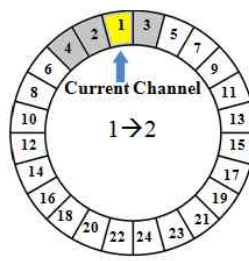

(a)

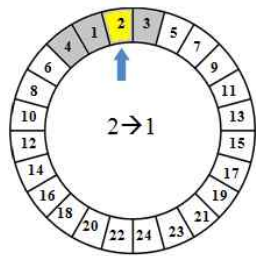

(e)

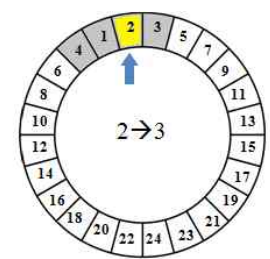

(b)

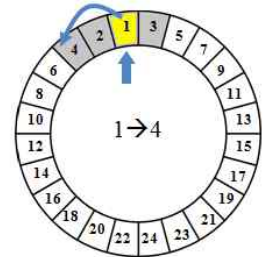

(f)

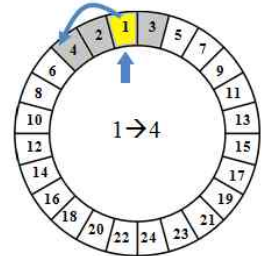

(i)

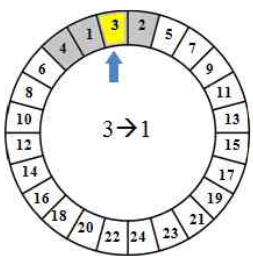

(c)

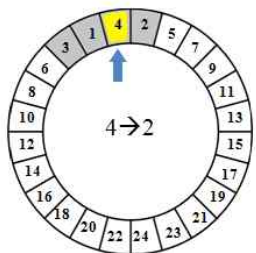

(g)

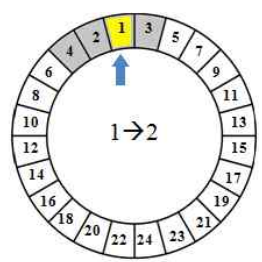

(d)

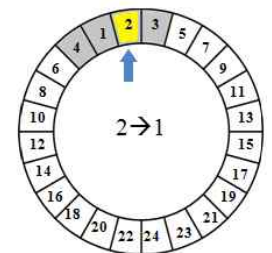

(h)

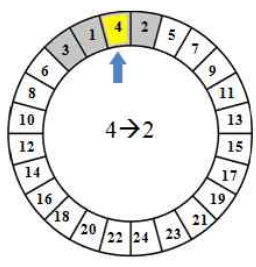

(j)

Fig. 3. A dynamic channel surfing scheme for preference channel recommendation.

Channel selection frequency priority: (1) $\rightarrow$ (2) $\rightarrow$ (3) $\rightarrow$ (1) $\rightarrow$ (2) $\rightarrow$ (1) $\rightarrow$ (4) $\rightarrow($ (2) $\rightarrow($ (1) $\rightarrow$ (4) $\rightarrow$ (1). 그림 3. 선호 채널 추천을 위한 동적 채널 배치 Channel Selection : ch.3 ch.15 ch.9 ch.3 ch.15 ch.3 ch.20 ch.15 ch.3 ch.20 ch.3

Frequency Priority

(2) (3) (1) (2)

(1) (4)

(2)

(1) (4) (1)

\begin{tabular}{|c|c|c|}
\hline Search Methods & Total Channel Seek Distance & Improvement \\
\hline (1) Numerical ordering & $12+6+6+12+12+7+5+12+7=86$ & $100 \%(1 / /(1) * 100)$ \\
\hline (2) Frequency circular ordering & $1+1+2+1+1+3+2+1+3+3=18$ & $20.9 \%((2) /(1) * 100)$ \\
\hline (3) Frequency interleaved ordering & $1+2+1+1+1+2+1+1+2+2=14$ & $16.3 \%(3) /(1) * 100)$ \\
\hline (4) Dynamic channel surfing scheme & $1+1+1+1+1+2+1+1+2+1=12$ & $14.0 \%(4 / / 1) * 100)$ \\
\hline
\end{tabular}

Channel Selection

: ch.3 ch.15 ch.18 ch.3 ch.15 ch.3 ch.6 ch.15 ch.3 ch.6 ch.3

Frequency Priority $:(1) \quad(2) \quad(6)$

(1) (2) (1)

ch.3 ch.6 ch.15

Search Methods

Total Channel Seek Distance

(1) Numerical ordering $12+3+9+12+12+3+9+12+3+3=78$

(2) Frequency circular ordering $1+4+5+1+1+7+6+1+7+7=40$

(3) Frequency interleaved ordering $1+6+3+1+1+4+3+1+4+4=28$

(4) Dynamic channel surfing scheme $1+3+1+1+1+4+1+1+4+1=18$

Fig. 4. Comparison of total channel seek distance.

그림 4. 채널 탐색 거리 비교 


\section{Experimental Results}

To evaluatethe efficiency of the proposed dynamic channel surfing scheme method, we use Zipf's ranked distribution to represent channel popularity [20], where the rth ranked popularity is calculated by:

$$
p(r)=r^{-\alpha},
$$

where $a$ is the Zipf rank exponent. When $a=0$, all popularities are equal. As $a$ increases, the distribution is skewed with respect to a lower order $r$.

We tested the four methods, numerical ordering, frequency circular ordering, frequency interleaved ordering [1], and the proposed dynamic channel surfing scheme, via two experiments, in which the number of requested channels in the trace is 10,000. As the number of channels $(N)$ increases, the average seek distances, which are the average numbers of channel changes for seeking channels, were calculated in the first experiment, where $a=0.5$ and the number of popular channels $\left(N_{P}\right)$ was $N / 2$. In the second experiment, the average seek distances of the four methods were calculated with respect to $a$, where $N=150$ and $N_{P}=N / 2$.

The first and second comparisons are shown in Figs. 5 and 6 respectively. The average channel seek distance for the proposed method is significantly shorter than those obtained using other methods.

Fig. 5 shows the average channel seek distances of the four methods as the number of DTV channels increases. As shown, the proposed dynamic channel surfing scheme outperforms the other methods when the number of channels is sufficiently large. Specifically, when the number of DTV channels is 150, the dynamic channel surfing scheme requires an average seek distance of 12.2 to find the requested channel, while the numerical ordering, frequency circular ordering, and frequency interleaved ordering methods require $37.9, \quad 25.7$, and 20.1, respectively.

Fig. 6 shows the average channel seek distances of the four methods as functions of the Zipf rank exponent. As the value of the Zipf rank exponent $a$ increases, the performance gap between the numerical ordering and the other methods becomes wider. Specifically, the performance improvement of the dynamic channel surfing scheme compared to the frequency interleaved ordering is up to $13.1 \%$ in terms of the average channel seek distance when the Zipf rank exponent is set to 1.0 .

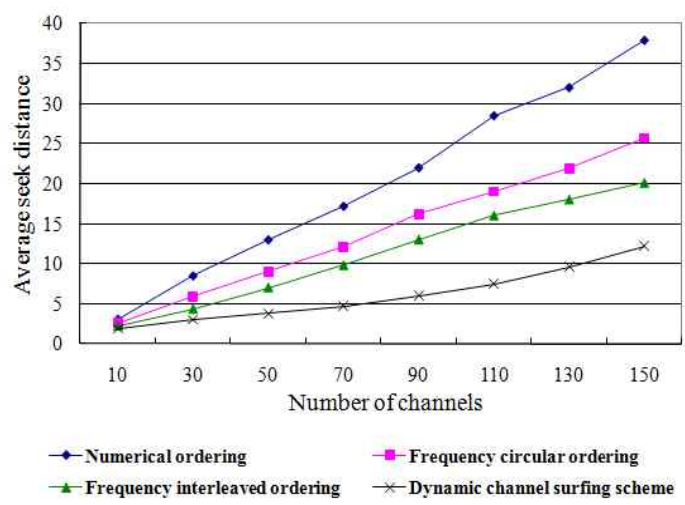

Fig. 5. Comparison of average channel seek distance with respect to $N\left(a=0.5, N_{P}=N / 2\right)$ 그림 5. 채널 수에 따른 평균 채널 탐색 거리 비교

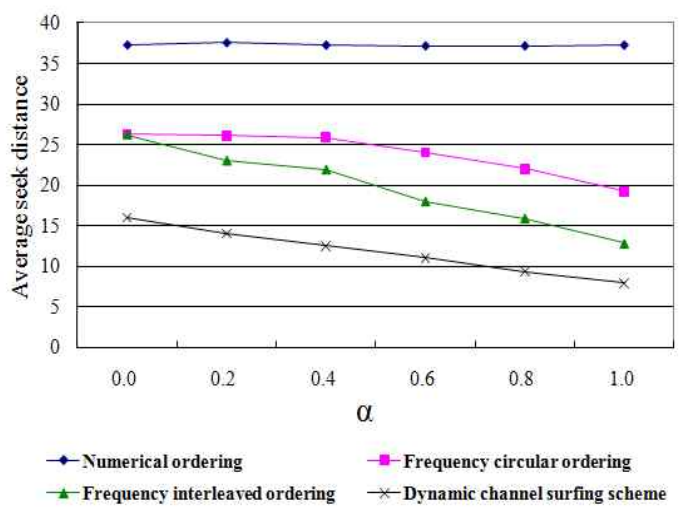

Fig. 6. Comparison of average channel seek distance with respect to $a\left(N=150, N_{P}=N / 2\right)$.

그림 6. $a$ 에 따른 평균 채널 탐색 거리 비교 


\section{Conclusions}

We have demonstrated that, given a channel selection interface limited to up-down buttons, consumers are required to spend more channel seek time or channel seek distance as the number of channels and programs increases. To refine these channel selection processes and to satisfy consumer requirements, we proposed a dynamic channel surfing scheme that dynamically rearranges channels according to priority around the position of the channel currently being watched, regardless of the current channel's actual priority.

We determine whether the user is in watching mode or surfing mode at the selected channel according to the time spent at each channel, and in watching mode the channels are dynamically rearranged on the left or right side according to their frequency priority.

This proposed dynamic channel surfing scheme is an efficient way to reduce channel seek distance regardless of priority. The results improve even more as the number of total channels increases. In the future, we will consider a way to reduces channel zapping time based on surfing behavior.

\section{Reference}

[1] E. Lee, J. Whang, U. Oh, K. Koh, and H. Bahn, "Popular channel concentration schemes for efficient channel navigation in internet protocol televisions," IEEE Trans. Consum Electron., Vol. 55, No. 4, pp. 1945-1949, 2009.

[2] R. Sotelo, Y. Blanco-Fernandez, M. Lopez-Nores, A. Gil-Solla, and J. Pazos-arias, "TV program recommendation for groups based on multidimensional TV-anytime classifications," IEEE Trans.ConsumElectron., Vol. 55, No.1, pp. 248-256, Feb. 2009.

[3] Z. Yu , X. Zhou , D. Zhang, C. Chin , X. Wang, and J. Men, "Supporting Context-Aware Media Recommendations for Smart Phones," IEEE Pervasive Computing, Vol. 5, No. 3, pp. 68-75, Jul-Sep. 2006.

[4] Z. Yu and X. Zhou, "TV3P: An Adaptive assistant for Personalized TV," IEEE Trans.Consum Electron., Vol.50, No.1, pp.393-399, Feb.2004.

[5] L. Kurapati, S. Gutta, D. Schaffer, J. Martino and J. Zimmeman, "A multi-agent TV recommender," in Proceedings of the International Conference on User Mbdeling 2001, Workshop on Personalization in Future TV, Sonthofen, Germany, 2001.

[6] W. Lee and J. Wang, "A User Centered Remote Control System for Personalized Multimedia Chamnel Selection," IFEE Trans.ConsumElectron., Vol.50, No.4, pp.1009-1015, Nov.2004.

[7] P. Resnick and H. R. Varian, "Recommender systems," Communications of the ACM, Vol. 40, No. 3, pp. 56-58, Mar. 1997

[9] C. Basu, H Hirsh and W. Cohen, "Recommendation as classification: using social and content-based information in recommendation," In Proceedings of the 15th National Conference on Artificial Intelligence (AAAI'98), pp. 714-720, 1998.

[9] T. Pessemier, T. Deryckere, K. Vanhecke, and L. Martens, "Proposed architecture and algorithm for personalized advertising on iDTV and mobile devices," IEEE Trans.Consum.Electron., Vol. 54, No. 2, pp.709-713, May. 2008.

[10] A. Martinez, J. Arias, A Vilas, J. Garcia, and M. Lopez, "What's on TV tonight? An efficient and effective personalized recommender system of TV programs," IEEE Trans.ConsumElectron., Vol.55, No.1, pp. 286-294, Feb. 2009.

[11] Y. Chen, H Huang, and Y. Huang,

"Community-based program recommendation for the next generation electronic program guide," IEEE Trans. ConsumElectron., Vol.55, No.2, pp. 707-712, May 2009.

[12] P. Cotter and B. Smyth, "PTV: Intelligent Personalised TV Guides," in Proceedings of the 12th Innovative Applications of Artificial 
Intelligence Conference (IAAI 2000), pp. 957-964, Austin, Texas, 2000.

[13] P. Resnick, N Iacovou, M Suchack, P. Bergstrom, and J. Riedl, "GroupLens: An Open Architecture for Collaborative Filtering of Netnews," in Proceedings of the ACM Conference on Computer Supported Cooperative Work, pp. 175-186, 1994.

[14] H. Lee, S. Lee, H. Kim, and H. Bahn,

"Personalized Recommendation Schemes for DTV Channel Selectors," IEEE Trans. Consum. Electron., Vol. 52, No. 3, pp. 1064-1068, Aug. 2006.

[15] H. Bahn, and Y. Baek, "An intelligent channel navigation scheme for DTV channel selectors," IEEE Trans. Consum. Electron., Vol. 54, No. 3, pp. 1098-1102, Aug. 2008.

[16] C. Cho, I. Han, Y. Jun and H Lee, "Improvement of Channel Zapping Time in IPTV Services Using the Adjacent Groups Join-Leave Method," Proceedings of the 6th International Conference on Advanced Communication Technology, Vol. 2, pp. 971-975, 2004.

[17] M. Mamun-Or-Rashid, D.S. Kim and C.S. Hong, "A Channel Management Framework to Construct User Preferred Fast Channel Change Stream in IPTV," Proceedings of 11th Asia-Pacific Network Operations and Management Symposium, Beijing, China, 2008.

[18] Y. Kim, J.K. Park, H.J. Choi, S. Lee, H. Park, J. Kim, Z. Lee and K. Ko, "Reducing IPTV Channel Zapping Time Based on Viewer's Surfing Behavior and Preference," Proceedings of IEEE International Symposium on Broadband Multimedia Systems and Broadcasting, 2008.

[19] C.H. song, L.K. Choi, "A construction method for IP-based Fixed and Personalized A/V Mosaic EPG service", Journal of the Korea Society of Computer and Information, Vol.11, No.5, pp. 39-52, Nov. 2006.

[20] L.A. Adamic and B.A. Huberman, "Zipf's law and the Internet," Glottometrics, Vol. 3, pp. 143-150, 2002.

\section{저 자 소 개}

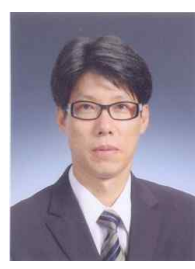

이 승 관

1997년 2월 : 경희대학교 전자계산 공학과 공학사

1999년 2월 : 경희대학교 전자계산 공학과 공학석사

2004년 2월 : 경희대학교 전자계산 공학과 공학박사

2004년 3월 2006년 8월 :

가톨릭대학교 컴퓨터정보공학부 강의

전임 교수

2006년 9월 현재 :

경희대학교 학부대학 조교수

관심분야 : 인공지능, 로봇에이전트, 최적화, 데이터마이닝, 영상처리

E-mail :leesg@khu.ac.kr

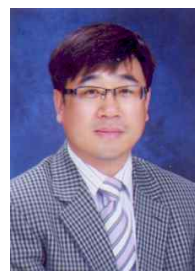

최 진 혁

1990년 2월 : 경희대학교 수학과 이학사

1992년 2월 : 경희대학교 수학과 이학석사

2003년 8월 : 경희대학교 수학과 이학박사

2004년 9월 2005년 3월 : 경희대학교 강의 전임 교수 2005년 4월 현재 경희대학교 학부대학 조교수 관심분야 : 리만기하학, 영상처리 E-mail :jinhchoi@khu.ac.kr 